\title{
The Influence of Corporate Governance Perception Index, Profitability, and Company Size on Stock Value on Go Public Companies at CGPI Listed On the Indonesia Stock Exchange
}

\author{
Ika Swasti Putri ${ }^{*}$, Siti Hayati Efi Friantin, \& Dino Aryanto \\ STIE Adi Unggul Bhirawa, Mr. Sartono Street No.46, Surakarta, Indonesia
}

\begin{abstract}
This research aims to determine the impact of corporate governance perception index, profitability, and company size on the value of CGPI-listed companies listed on the Indonesian Stock Exchange for three years. The data used in this study are second-hand data. The data for this research comes from the company's 2017-2019 annual report for the observation period. Using purposeful sampling methods, samples were obtained from as many as 16 companies using data collection techniques. The data analysis methods used in this study are multiple linear regression analysis, classical hypothesis testing, and hypothesis testing. The results show that the impact of corporate governance perception index, profitability, and company size also affect stock value. The influence of the independent variable on the dependent variable is $37.7 \%$, and the remaining $62.3 \%$ are affected by variables other than this study. For partial results, the influence of the Corporate Governance Perception Index and Profitability and has a significant positive effect on Share Value, while the size of the company has no significant positive effect on the value of the share.
\end{abstract}

Keywords: CGPI, Profitability, Company Size, Share Value.

\section{Introduction}

Share value is the value per share prevailing in the capital market. The value of shares is a very important factor and must be considered by investors in investing because the value of shares shows the achievements of the issuer. Simply put, shares can be defined as proof of ownership of a company, and shareholders are entitled to the income and assets of the company. The reward that will be obtained with share ownership is dividends or capital gains. Capital gain is the profit from selling or buying shares in the form of excess selling value from the purchase value of shares. The stock value index is an indicator that shows the movement of the stock value. Analysis in assessing stock value can be through the company's fundamental analysis through its financial ratio analysis and can be through technical analysis by looking at the movement of stock value (Runtu et al., 2015).

The Corporate Governance Perception Index (CGPI) is the result of an evaluation and classification conducted by the Indonesian Institute for Corporate Governance (IICG) on the implementation of corporate governance of companies listed on the Indonesia Stock Exchange (IDX). Good Corporate Governance according to (Prakarsa, 2007) is as follows: "Good Corporate Governance is an administrative mechanism that regulates the relationships between company management, commissioners, directors, shareholders and other interest groups (stakeholders). These relationships are manifested in the form of various rules of the game and an incentive system as the necessary framework for determining the goals of the company and the means for achieving those goals and monitoring the resulting performance."

Profitability is the ability of a company to generate profits over a period of time using specific sales, assets, and equity capital. A company's profitability can be assessed in different ways depending on its profits and assets or capital that

\footnotetext{
* Corresponding author.

E-mail address: ika@stie-aub.ac.id (Ika Swasti Putri)
} 
will be compared with one another. According to (Irawati, 2006) Profit ratios or profitability ratios are a metric Used to measure the company's ability to operate effectively, using company assets or the company's ability to generate profits in a specific period of time (usually semi-annually, quarterly, etc.).

Company size is the yardstick for classifying company size in various ways such as: size of income, number of employees, total assets, market value of shares, and total capital. According to (Eugene F, 2010) the size of the company is as follows: "Company size is a measure of the size of a company which is indicated or assessed by total assets, total sales, total profit, tax expense and others".

Research conducted by (Habibie, 2010) shows that the impact of corporate governance as a proxy for managerial share ownership, institutional share ownership and independent board of commissioners on stock value. This study takes samples from manufacturing companies listed on the IDX in the 2010 period. The research shows that there is no effect of managerial share ownership, institutional share ownership and independent board of commissioners on stock value.

(Berthelot et al., 2010), This study examines the impact of corporate governance ratings, book values, stocks, and net income on market development as a substitute for stock prices. This research takes a sample of data from the annual reports of Canadian companies and the Globe and mail using the 2002-2005 corporate governance rating. The results of this study indicate the influence of corporate governance rating on stock value because it shows investors use corporate governance rating to evaluate stock market value.

This research aims to determine the impact of corporate governance perception index, profitability, and company size on the value of CGPI-listed companies listed on the Indonesian Stock Exchange for three years. The difference with previous studies refers to research conducted by (Pratama, 2012) examining the relationship between Corporate Governance perception index and profitability with stock value. The results of the study show that CGPI does not affect stock value while profitability affects stock value. While in this study there is an increase in Profitability and Firm Size as independent variables, and stock value as the dependent variable. This study uses company data listed on the Indonesia Stock Exchange in 2017-2019, and the population in this study are Go Public companies that participate in the 2017-2019 CGPI.

\section{Literature Review}

\subsection{Share Value}

Share value is the value per share prevailing in the capital market. The value of shares is a very important factor and must be considered by investors in investing because the value of shares shows the achievements of the issuer. In simple terms, shares can be defined as certificates that show proof of ownership of a company and shareholders have claim rights to the company's income and assets. The reward that will be obtained with share ownership is dividends or capital gains. Capital gain is the profit from selling or buying shares in the form of excess selling value from the purchase value of shares. The stock value index is an indicator that shows the movement of the stock value. Analysis in assessing stock value can be through the company's fundamental analysis through its financial ratio analysis and can be through technical analysis by looking at the movement of stock value (Runtu et al., 2015). The stock market value is the value of the shares listed on the stock exchange based on the determination by market participants. According to Musdalifah Azis (2015: 80), the value of shares is defined as follows: "The value in the real market, and is the most easily determined price because it is the value of a share in the ongoing market or if the market is closed".

\subsection{The Corporate Governance Perception Index (CGPI)}

The Corporate Governance Perception Index (CGPI) is the result of an assessment and ranking of the implementation of corporate governance in companies listed on the Indonesia Stock Exchange (IDX) conducted by The Indonesian Institute for Corporate Governance (IICG). Good Corporate Governance according to (Prakarsa, 2007) is as follows: "Good Corporate Governance is an administrative mechanism that regulates the relationships between company management, commissioners, directors, shareholders and other interest groups (stakeholders). These relationships are 
manifested in the form of various rules of the game and an incentive system as the necessary framework for determining the goals of the company and the means for achieving those goals and monitoring the resulting performance." In Indonesia, it has begun to be widely discussed in the business world, so that many sources of corporate governance have begun to be researched within the company and then developed by corporate governance research institutions, one of the information related to corporate governance currently that can be used is the corporate governance perception index ( CGPI). The CGPI index is the result of research from an institution organized by The Indonesian Institute for Corporate Governance (IICG) in collaboration with SWA magazine, where this CGPI has been made since 2001. The purpose of the Corporate governance perception index is to rank the best index for each company that has implemented corporate governance. With the existence of the corporate governance perception index, it is hoped that it will be useful for management and investors. As for the management, CGPI is useful as a material for evaluating the company regarding the level of governance that has been implemented in the company so that it can improve company performance which is expected to also increase share value. As with CGPI in previous years, CGPI was attended by a total of 29 companies as participants. Each participating company has followed two stages of assessment, namely the analysis and observation stages. The analysis stage is carried out by filling out a questionnaire (self-assessment) and evaluating company documents, while the observation stage uses the executive exposure method and active discussion between the assessment team and the Company's Organs. Aspects of the assessment of the CGPI include the governance structure, the governance process, and governance outcomes which are described in several indicators using a stakeholder perspective. The results of the CGPI ranking in the form of scores and indexes are grouped into three categories of confidence levels, namely the VERY RELIABLE (score 85100), RELIABLE (score 70-84) and ENOUGH RELIABLE (score 55-69).

\subsection{Profitability}

Profitability is the ability of a company to generate profits during a certain period at a certain level of sales, assets and share capital. The profitability of a company can be assessed in various ways depending on the profits and assets or capital that will be compared with one another. Irawati (2006:58) states that the profit ratio or profitability ratios is a ratio used to measure the efficiency of the use of company assets or is the ability of a company to generate profits during a certain period (usually semiannual, quarterly and others) to see the company's ability to operate. efficiently. Profitability is the company's ability to generate company profits. High profitability in the company can make investors interested in the company, because the company is considered to be able to generate profits effectively.

\subsection{Company Size}

Company size is a size, scale or variable that describes the size of the company based on several provisions, such as total assets, log size, market value, shares, total sales, total income, total capital and others (Eugene F, 2010). The grouping of companies based on the scale of operation is generally divided into three categories, namely: large firms, medium-size companies and small firms. Company size indicators can be done in two ways, namely:

a) Company Size $=$ Ln Total Assets/Assets. Assets are the resources or assets of the company. Where the greater the assets, the company can invest well and product demand can be met.

b) Organization size $=$ Ln Total Sales. Sales is a marketing function so that the company's goal to earn a profit can be achieved. If there is a constant increase in sales, the production costs can be covered. In other words, the company's profit will also increase and will have an influence on the company's profitability.

\section{Research Methods}

This research is an empirical study with the aim of knowing the effect of Corporate Governance Preception Index (CGPI), Profitability and Firm Size on stock value. This study utilizes data on the financial statements of Go public companies on CGPI which are listed on the Indonesia Stock Exchange. The data source used is secondary data. Secondary data is obtained by accessing online www.idx.co.id by downloading all published financial reports according to predetermined sample criteria, and CGPI values obtained from SWA magazine. Data analysis method used in this research is multiple linear regression analysis. According to (Bungin, 2011), multiple linear regression analysis is used to predict how the value of the dependent variable changes when the value of the independent variable is increased or decreased. The sampling technique was purposive sampling with the criteria of the company providing complete reports and data needed by researchers on the Indonesia Stock Exchange. 
Tabel 1. Criteria of Sample

\begin{tabular}{lc}
\hline \multicolumn{1}{c}{ Criteria } & Total \\
\hline Participating Companies in the Corporate Governance Perception Indexs (CGPI). & 29 \\
Number of Samples That Go Public at CGPI and Publish Annual Reports & 16 \\
Research Period & 3 \\
Number of Samples & 48 \\
\hline
\end{tabular}

\section{Research Result}

\subsection{Descriptive Statistical Analysis}

The variables analyzed in this study include: Corporate Governance Perception Indexs, Profitability, Firm Size and Share Value. Descriptive statistics of research variables in the following table:

Table 2. Descriptive Statistic

\begin{tabular}{lccccr}
\hline & N & Min & Max & Mean & Std. Deviation \\
\hline CGP & 48 & 0,86 & 0,96 & 0,8088 & 0,08076 \\
Profitability & 48 & 0,00 & 9,45 & 0,5652 & 2,28976 \\
Size Company & 48 & 0,11 & 0,30 & 0,1879 & 0,04925 \\
Share Value & 48 & 0,00 & 0,02 & 0,0108 & 0,00440 \\
Valid N & 48 & & & & \\
\hline
\end{tabular}

Based on the table shows that from 48 data variables. Share value has an average value of 0.0108 with a standard deviation of 0.00440 . Company size has an average value of 0.1879 with a standard deviation of 0.04925 where company (MFIN) has the lowest value of 0.11 and company (WSKT) has the highest value of 0.30 . Profitability has a value of 2.5652 with a standard deviation of 2.2897 where the company (CENT) has the lowest value of 0.00 and the company (BBCA) has the highest value of 9.45. The Corporate Governance Perception Indexs have an average value of 0.8088 with a standard deviation of 0.08076 where the company (NISP) has the lowest value of 0.68 and the company (BBCA).

\subsection{Normality Test}

Aims to assess the distribution of data on a variable, whether the independent or dependent variable has a normal distribution or not (Ghozali, 2018). The basis for decision making for the normality test is the Kolmogorov-Smirnov as follows:

a) If the significant value ( $\mathrm{sig}$ ) is greater than 0.05 , then the research data is normally distributed.

b) If the significant value ( $\mathrm{sig}$ ) is less than 0.05 , then the research data is not normally distributed

Table 3. Kolmogorov Smirnov

\begin{tabular}{|c|c|c|}
\hline & & $\begin{array}{l}\text { Unstandardized } \\
\text { Residual }\end{array}$ \\
\hline \multicolumn{2}{|l|}{$\mathrm{N}$} & 48 \\
\hline \multirow[t]{2}{*}{ Normal Parameters ${ }^{\mathrm{ab}}$} & Mean & ,0000000 \\
\hline & Std. Deviation &, 00336281 \\
\hline Most Extreme & Absolute & 071 \\
\hline \multirow[t]{2}{*}{ Differences } & Positive &, 050 \\
\hline & Negative &,- 071 \\
\hline \multicolumn{2}{|c|}{ Kolmogorov-Smirnov Z } & ,495 \\
\hline \multicolumn{2}{|l|}{ Asymp. Sig. (2-tailed) } & 967 \\
\hline
\end{tabular}


Based on the Table of Normality Test Results obtained Asymp. Sig. (2-tailed) of $0.967>0.05$, it can be concluded that the data has passed the normalization test or the data is normally distributed.

\subsection{Heteroscedasticity test}

Heteroscedasticity test is carried out with the Gletier Test where it can be seen whether in the regression method there is an inequality of variance from one observation residual to another observation. The criteria used according to (Ghozali, 2018 ) is if the value of sig $<0.05$ then the model has heteroscedasticity. However, if sig $>0.05$ then there is no heteroscedasticity. It can be seen in the heteroscedasticity test table below.

Table 4. Glejser Test

\section{Coefficients $^{\mathbf{a}}$}

\begin{tabular}{|c|c|c|c|c|c|}
\hline \multirow[t]{2}{*}{ Model } & \multicolumn{2}{|c|}{$\begin{array}{l}\text { Unstandardized } \\
\text { Coefficients }\end{array}$} & \multirow{2}{*}{$\begin{array}{c}\text { Standardized } \\
\text { Coefficients } \\
\text { Beta }\end{array}$} & \multirow[t]{2}{*}{$\mathrm{t}$} & \multirow[t]{2}{*}{ Sig. } \\
\hline & $\mathrm{B}$ & Std. Error & & & \\
\hline 1 (Constant) &,- 001 & ,003 & &,- 337 & ,738 \\
\hline CGP & ,006 & ,004 & ,219 & 1,494 &, 142 \\
\hline Profitability & -006 & ,000 & ,040 & ,273 & ,786 \\
\hline Size Company &,- 005 & ,006 &,- 125 &,- 850 & ,400 \\
\hline
\end{tabular}

${ }^{a}$ Dependet Variable : Share Value

Based on Table IV.3 the Glacier Test shows that the Corporate Governance Perception Indexs variable has a significant value of $0.142>0.05$, Profitability has a significant value of $0.786>0.05$ and Company Size has a significant value of $0.400>0.05$. then it can be stated that there is no heteroscedasticity.

\subsection{Multicollinearity test}

Multicollinearity test was conducted to determine the correlation between the independent variables used in the research. To test Multicollinearity, Variant Inflation Factor (VIF) and Tolerance numbers will be used. A good regression model is that there is no correlation between the independent variables. The criteria for determining multicollinearity are if the tolerance value is $<0.1$ and the Variant Inflation Factor (VIF) $>10$, then there is multicollinearity (Ghozali, 2018). The results of the calculation of the multicollinearity test are presented in the following table:

Table 5. Multicollinearity Test

\begin{tabular}{|c|c|c|c|c|c|c|c|}
\hline \multirow[t]{2}{*}{ Model } & \multicolumn{2}{|c|}{$\begin{array}{c}\text { Unstandardized } \\
\text { Coefficients }\end{array}$} & \multirow{2}{*}{$\begin{array}{c}\text { Standardized } \\
\text { Coefficients } \\
\text { Beta } \\
\end{array}$} & \multirow[t]{2}{*}{$\mathrm{t}$} & \multirow[t]{2}{*}{ Sig. } & \multicolumn{2}{|c|}{ Colinearity State } \\
\hline & $\mathrm{B}$ & Std. Error & & & & Tolerance & VIF \\
\hline 1 (Constant) & ,016 & ,006 & & ,833 & ,007 & & \\
\hline CGP &, 028 & ,006 & ,517 & ,439 &, 000 & ,977 & 023 \\
\hline Profitability &, 001 & ,000 & ,325 & ,766 & ,008 & ,962 & ,039 \\
\hline Size Company &, 012 &, 010 &, 136 &, 167 & ,250 & ,977 & ,023 \\
\hline
\end{tabular}

${ }^{\text {a} D e p e n d e t ~ V a r i a b l e ~: ~ S h a r e ~ V a l u e ~}$

Based on the table shows that each independent variable has a tolerance value of more than 0.10 and the VIF value is less than 10. It can be concluded that the regression model in this study does not have multicollinearity between independent variables.

\subsection{Autocorrelation test}

Autocorrelation test is conducted to determine whether there is a chain correlation between the factors that are considered sequentially. In this study, the test that can be done to detect the presence or absence of autocorrelation is to perform the 
Durbin Watson Test (DW Test). Autocorrelation arises because successive observations over time are related to each other. The decision making whether there is autocorrelation is as follows:

1) If the DW value is below -2 , then there is a positive autocorrelation.

2) If the $D W$ value is between -2 to +2 , then there is no autocorrelation.

3 ) If the DW value is above +2 , then there is a negative autocorrelation.

Table 6. Durbin Watson Test

Model Summary ${ }^{\mathbf{b}}$

\begin{tabular}{lcrrrr}
\hline Model & $\mathrm{R}$ & $\mathrm{R}$ Square & Adjusted R Square & Std. Error Estimate & Durbin-Watson \\
\hline 1 &, $646^{\mathrm{a}}$ &, 417 &, 377 &, 00348 & 1,055 \\
\hline
\end{tabular}

a. Predictors : (Constant), Size Company

b. Dependent Variabel : Share Value

Based on the results of the table shows the Durbin-Watson value of 1.055. The table shows a number of 1.055 which is between -2 to $<+2$ so it can be concluded that the results of the DW test show that there is no autocorrelation.

\subsection{Multiple linear regression analysis}

Multiple linear regression analysis, namely the study of the dependence of an independent variable (bound) and independent variable (free) with the aim of estimating and or predicting the population average or the average value of the dependent variable based on the known independent variable values (Ghozali, 2018).

Table 7. Multiple Linear Regression

Coefficients $^{\text {a }}$

\begin{tabular}{|c|c|c|c|c|c|c|c|}
\hline \multirow[t]{2}{*}{ Model } & \multicolumn{2}{|c|}{$\begin{array}{l}\text { Unstandardized } \\
\text { Coefficients }\end{array}$} & \multirow{2}{*}{$\begin{array}{c}\text { Standardized } \\
\text { Coefficients } \\
\text { Beta }\end{array}$} & \multirow[t]{2}{*}{$\mathrm{T}$} & \multirow[t]{2}{*}{ Sig. } & \multicolumn{2}{|c|}{ Colinearity State } \\
\hline & $\mathrm{B}$ & Std. Error & & & & Tolerance & VIF \\
\hline 1 (Constant) & ,016 & ,006 & & ,833 & ,007 & & \\
\hline CGP & ,028 & ,006 & ,517 & ,439 & ,000 & ,977 & ,023 \\
\hline Profitability & ,001 & ,000 & ,325 & ,766 & ,008 & ,962 & ,039 \\
\hline Size Company & ,012 & ,010 & , 136 & , 167 & ,250 & ,977 & ,023 \\
\hline
\end{tabular}

aDependet Variable : Share Value

Based on the results of the regression calculations in the table, the multiple regression equation model is obtained as follows:

$$
Y=-0,016+0,028 X_{1}+0,001 X_{2}+0,012 X_{3}+e
$$

The regression equation above can be described as follows:

1) The constant value is - 0.016 , meaning that if the value of the independent variable Cooperate Governance Perception Indexs, Profitability and Company Size is zero, then the dependent variable is -0.016 .

2) Coefficient of Cooperate Governance Perception Indexs $\left(X_{1}\right)=0.028$, meaning that every $1 \%$ addition of Cooperate Governance Perception Indexs will increase Share Value by 0.028 . Assuming other variables are considered constant.

3) Profitability Coefficient $\left(\mathrm{X}_{2}\right)=0.001$, meaning that every $1 \%$ increase in Profitability will increase the Share Value by 0.001 . Assuming other variables are considered constant.

4) Company Size Coefficient $\left(\mathrm{X}_{3}\right)=0.012$, meaning that every $1 \%$ increase in Company Size will increase the Share Value by 0.012 . Assuming other variables are considered constant. 


\subsection{T-Test}

The $t$ test or partial test is intended to determine whether the independent variables individually have an influence on the dependent variable (Y) with the assumption that the other variables are constant. Decision making basis:

1) If profitability is significant $<0.05$, then $\mathrm{H}_{0}$ is rejected and $\mathrm{H}_{1}$ is accepted, meaning that the $\mathrm{X}$ variable partially affects the stock value $(\mathrm{Y})$.

2) If profitability is significant $>0.05$, then $\mathrm{H}_{0}$ is accepted and $\mathrm{H}_{1}$ is rejected, meaning that partially the $\mathrm{X}$ variable has no effect on the stock value (Y).

Table 8. T-Test

\begin{tabular}{|c|c|c|c|c|c|c|c|}
\hline \multicolumn{8}{|c|}{ Coefficients $^{\mathbf{a}}$} \\
\hline \multirow[t]{2}{*}{ Model } & \multicolumn{2}{|c|}{$\begin{array}{l}\text { Unstandardized } \\
\text { Coefficients }\end{array}$} & \multirow{2}{*}{$\begin{array}{l}\text { Standardized } \\
\text { Coefficients } \\
\text { Beta }\end{array}$} & \multirow[t]{2}{*}{$\mathrm{T}$} & \multirow[t]{2}{*}{ Sig. } & \multicolumn{2}{|c|}{ Colinearity State } \\
\hline & $\mathrm{B}$ & Std. Error & & & & Tolerance & VIF \\
\hline 1 (Constant) & ,016 & ,006 & & ,833 & ,007 & & \\
\hline CGP & ,028 &, 006 & ,517 & ,439 & ,000 & ,977 & 023 \\
\hline Profitability &, 001 & ,000 &, 325 &, 766 & ,008 & ,962 & 039 \\
\hline Size Company &, 012 &, 010 & ,136 &, 167 &, 250 & ,977 &, 023 \\
\hline
\end{tabular}

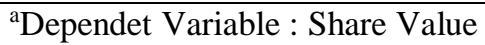

Based on the results of the $t$ test in Table 8 it can be concluded that:

1) The Corporate Governance Perception Indexs variable has a t count of 4.439 and a significant value of 0.000 . The results of the study obtained a significant value of $0.000<0.05$, then $\mathrm{H}_{0}$ was rejected and $\mathrm{H}_{1}$ was accepted, meaning that the Corporate Governance Perception Indexs had a significant positive effect on the Company's Stock Value.

2) Profitability variable has a t count of 2.776 and a significant value of 0.008 . The results obtained a significant value of $0.008<0.05$, then $\mathrm{H}_{0}$ is rejected and $\mathrm{H}_{2}$ is accepted, meaning that profitability has a significant positive effect on the value of the company's shares.

3) Firm Size variable has a t count of 1.167 and a significant value of 0.250 . The results obtained a significant value of $0.250>0.05$, then $\mathrm{H}_{0}$ is accepted and $\mathrm{H}_{3}$ is rejected, meaning that the size of the company has no significant effect on the value of the company's shares.

\subsection{F-Test}

The test results using the SPSS program can be seen in the following table with a significant level of 5\% $(\alpha=0.05)$.

\begin{tabular}{lrrrrr}
\multicolumn{7}{c}{ Table 9. F-Test } \\
ANOVA
\end{tabular}

a. Predictors : (Constant), Size Company

b. Dependent Variable : Share Value 
Based on the results of the $F$ test in the table, the results of the $F$ count test are 10,476 and with a significant level of 0.000 . Because it has a significantly smaller value than $(\alpha=0.05)$ which is 0.000 , then the Corporate Governance Perception Indexs, Profitability and Company Size together have a significant effect on the Company's Share Value.

\subsection{Coefficient of determination test $\left(R^{2}\right)$}

Table 10. Coefficient of determination test

\begin{tabular}{|c|c|c|c|c|c|}
\hline \multicolumn{6}{|c|}{ Model Summary ${ }^{\mathbf{b}}$} \\
\hline Model & $\mathrm{R}$ & R Square & Adjusted R Square & Std. Error Estimate & Durbin-Watson \\
\hline 1 & ,646 & ,417 & ,377 & ,00348 & 1,055 \\
\hline
\end{tabular}

Based on the table shows the Adjusted R Square value of 0.377 which means $37.7 \%$. So these results indicate that the variables of Corporate Governance Perception Indexs, Profitability and Company Size have the ability of $37.7 \%$ in running the Share Value. The remaining $62.3 \%$ is explained by other variables not included in the study. This means that there are other variables that have an influence on the Share Value.

\section{Implication}

Based on the results of data analysis, it shows that the Corporate Governance Perception Index (CGPI) has a significant positive effect on Stock Value. The higher the CGPI score means the more efficient the company's performance so that the possibility of the company being in a problematic condition is getting smaller, this will have a positive effect on the increase in the value of the company's shares. The higher the CGPI score achieved by the Company, the more efficient the company's activities in generating profits. In this case, it can be concluded that the lower the CGPI score, the greater the possibility that the Company will be in trouble, so there is also the possibility that the Company's Share Value will decrease. The results of this study are consistent with research conducted by (Indriani, 2018) which states that Corporate Governance Perception Indexs (CGPI) have a significant effect on stock values.

Based on the results of data analysis shows that profitability has a significant positive effect on stock value. The higher the profitability means the more efficient the performance of the company so that the possibility of the company being in a problematic condition is getting smaller, this will have a positive effect on the increase in the value of the company's shares. The higher the level of profitability achieved by the company means the more efficient the company's activities in generating profits. In this case, it can be concluded that the lower the level of profitability, the greater the possibility that the company will be in trouble, so there is also the possibility that the value of the company's shares will decrease. The results of this study are consistent with research conducted by (Rosalita, 2021) which states that profitability has a significant effect on stock value.

Based on the results of the discussion, it shows that the size of the company has no significant effect on the value of shares. In this case, it can be concluded that the size of the company will not affect the value of the company's shares. These results indicate that the size of the company has nothing to do with the value of the company's shares. In addition, the possibility that the size of the company is not the only consideration for investors in making investment decisions but there are other factors that are more important to consider in making investment decisions such as the level of investment. profits, the company's business prospects in the future and so on. The results of this study are consistent with research conducted by (Indracahya \& Faisol, 2017) which states that company size has no significant effect on stock value.

\section{Conclusion}

Based on the results of research that has been carried out, the following conclusions are drawn: The results of the Corporate Governance Perception Indexs (CGPI) test have a significant positive effect on the Company's Share Value. This means that the higher the CGPI score, the higher the share value. So Accepted. The higher the CGPI score indicates how good the corporate governance is. The higher the CGPI score, the higher the share value of the company. 
Profitability test results have a significant positive effect on the Company's Share Value. This means that the higher the level of profitability, the higher the share value. Then it is accepted, the higher the level of profitability indicates how well the company's performance is. With the higher the level of profitability, the higher the share value of the company. The results of the Company Size test do not have a significant effect on the Company's Share Value. In this case, it can be concluded that the size of a company will not affect the value of the company's shares. The results of testing the Corporate Governance Perception Indexs (CGPI), Profitability and Company Size together have a significant effect on Share Value. The test results of the Determinant Coefficient of R2 show a value of 0.377 , meaning that it is known that the influence given by the independent variable on the dependent variable is $37.7 \%$ while the remaining $62.3 \%$ is influenced by other variables not included in the study.

\section{References}

Berthelot, S., Morris, T., \& Morrill, C. (2010). Corporate governance rating and financial performance : a Canadian study. October. https://doi.org/10.1108/14720701011085599

Bungin, B. (2011). Metode Penelitian Kuantitatif(11th ed.). Kencana.

Eugene F, B. (2010). Dasar-Dasar Manajemen Keuangan. Salemba Empat.

Ghozali, I. (2018). Penggunaan Analisis Multivariat dengan Program IBM SPSS 25. Lembaga Penerbit Universitas Diponegoro.

Habibie. (2010). Pengaruh Good Corporate Governance terhadap Harga Saham Perusahaan Manufaktur yang Terdaftar di Bursa Efek Indonesia Periode 2010. Malang University.

Indracahya, E., \& Faisol, D. A. (2017). The Effect of Good Corporate Governance Elemets, Leverage, Firm Age, Company Size and Profitability On Earning Management. Profita: Komunikasi Ilmiah Akuntansi Dan Perpajakan, 10(2), 203-227.

Indriani, A. (2018). PENGARUH INDEKS CORPORATE GOVERNANCE, LEVERAGE, PROFITABILITAS DAN UKURAN PERUSAHAAN TERHADAP NILAI PERUSAHAAN (Studi Empiris pada Perusahaan yang Terdaftar Konsisten dalam Penilaian CGPI Periode 2012-2016) [Universitas Diponegoro]. https://repofeb.undip.ac.id/id/eprint/2140

Irawati, S. (2006). Perpustakaan Pengelolaan Moneter (1st ed.).

Prakarsa, W. (2007). Corporate Governance: Suatu Keniscayaan. Jurnal Reformasi Ekonomi, 1(2), 20 -28.

Pratama. (2012). Pengaruh Corporate Governance Perception Index (CGPI) dan Profitabilitas Terhadap Harga Saham. Jurnal Ujian:Universitas Negeri Semarang.

Rosalita, A. (2021). Pengaruh Profitabilitas, Leverage, Likuiditas, dan Corporate Governance Terhadap Manajemen Laba pada Perusahaan Go Public yang Terdaftar di CGPI Tahun 2011-2017. Jurnal Akuntansi Unesa, 9(3), 112. https://journal.unesa.ac.id/index.php/akunesa/article/view/11446

Runtu, T., Poputra, A., \& Wangarry, A. (2015). Pengaruh Tingkat Return on Investment (Roi), Net Profit Margin (Npm), Dan Debt to Equity Ratio (Der) Terhadap Harga Saham Perbankan Di Bursa Efek Indonesia (Bei). Jurnal Riset Ekonomi, Manajemen, Bisnis Dan Akuntansi, 3(4), 470-477. 